Original Research Article

\title{
Effect of quercetin on histamine induced gastric ulcers in male guinea pigs
}

\author{
Uma Narayanamurthy ${ }^{1}$, Ranjani Jayachandran ${ }^{2}$, Sudar Codi Ramarajan ${ }^{1}$, \\ Manimekalai Kumarappan ${ }^{1}$, Kanan R. ${ }^{3}$, Barathane D. ${ }^{1}$
}

${ }^{1}$ Department of Pharmacology,

${ }^{3}$ Department of Surgery,

Mahatma Gandhi Medical

College and Research Institute,

Puducherry, India

${ }^{2}$ Department of Pathology, Christian Medical College,

Vellore, India

Received: 02 August 2019

Accepted: 03 August 2019

*Correspondence to:

Dr. Uma Narayanamurthy, Email: numa.lally@gmail.com

Copyright: (C) the author(s), publisher and licensee Medip Academy. This is an openaccess article distributed under the terms of the Creative Commons Attribution NonCommercial License, which permits unrestricted noncommercial use, distribution, and reproduction in any medium, provided the original work is properly cited.

\begin{abstract}
Background: Peptic ulcer disease is the most prevalent gastrointestinal diseases caused by an imbalance between gastric stimulant or aggressive factors and the mucosal defensive factors. The defence of flavonoids against the tissue oxidative stress is being proved in various animal models for wide pharmacological effects. The aim of the present study is to evaluate the antioxidant effect of quercetin in histamine induced gastric ulcers.

Methods: Male guinea pigs were divided into 4 groups $(n=6)$. Group I includes normal control. Group 2, 3 and 4 were induced gastric ulcers with histamine as intraperitoneal (IP) injection. Group 2 serves as the gastric ulcer control. Group 3 and Group 4 are pre-treated with quercetin $200 \mathrm{mg} / \mathrm{kg}$ per orally (PO) and ranitidine $100 \mathrm{mg} / \mathrm{kg}$ PO respectively $45 \mathrm{mins}$ before histamine injection. After 4 hours of histamine injection, the animals were sacrificed to collect blood samples and stomach tissue for estimation of plasma and tissue antioxidant levels.

Results: On estimation of antioxidant levels both in plasma and stomach tissues the SOD and CAT levels increased in the Group 3 and 4 significantly and also a significant reduction in MDA levels were noted in the Group 3 and 4 compared to the gastric ulcer control group.

Conclusions: Hence, with flavonoids quercetin utilization in histamine induced gastric ulcers, the antioxidants showed comparative levels with ranitidine treatment groups. So a permanent cure for the chronic gastric ulcers could be proved in further studies as this is the milestone, tough to achieve in general clinical practice.
\end{abstract}

Keywords: Peptic ulcer disease, Quercetin, Antioxidant effect, Stomach

\section{INTRODUCTION}

Peptic ulcer disease (PUD) is the most prevalent gastrointestinal (GI) diseases which consume more than 5 billion from the annual medical expenses. ${ }^{1}$ This condition leads to an estimated 15,000 surgical procedures performed on hospitalized individuals. ${ }^{1}$ PUD is caused by an imbalance between the stimulant or aggressive factors and the mucosal defensive factors. ${ }^{2}$ There is a strong association of PUD with antral gastritis.
The common defensive or protective factors are secretion of mucosal bicarbonate, mucus production, gastric tissue blood flow, growth factors, renewal of gastric cells and endogenous prostaglandins synthesis. The most common aggressive or gastric tissue damaging factors are secretion of hydrochloric acid, pepsins production, alcoholism, smoking and hypoxia due to the above mentioned factors, bile reflux in duodenum, gastric ischemia, NSAID's intake and most common factor $H$. pylori infections. 
When there is increased utilization of NSAID's there is spikes of hospitalization due to bleeding peptic ulcers. ${ }^{3}$ Hence, the risk of hematemesis is directly proportional to the NSAID's daily dosage, which is a factor of major importance at present in the GERD management. ${ }^{4}$ The presence of associated risk factors (age $>60, \mathrm{H} / \mathrm{O}$ prior GI events, concomitant steroids or anticoagulant medications) doubles the risk of upper GI bleed. This NSAID users with PUD are prone to $>10$ fold increased risks due to GI complications than the general population. The site of NSAID induced ulcers is stomach. Though the NSAID's ingestion remains as the key factor for common ulcer pathogenesis, leading to ultimate GI complications and death, the satisfactory factor in such type of gastric ulcers is that, on discontinuation of NSAID's the ulcers are non-recurrent and permanently cured.

Proton pump inhibitors and $\mathrm{H} 2$ receptor blockers are the two classes of drugs which revolutionized the PUD management. Most of the duodenal and gastric ulcers also could be healed by treatment with these drugs for a few weeks. ${ }^{4}$ Though there is rapid impressive symptom relief within few weeks of treatment with the above mentioned class of drug, the major problem faced with these anti-secretory agents is relapse, which is almost universally accepted phenomenon.

When speaking about relapse of the ulceration, GI disturbances are the ones which are the major hindrance to day to day health of a human being. So, there is always a hunger towards permanent solution. Here comes the role of flavonoids that are distributed extensively among the plant kingdom and are known for their antiinflammatory effect, anti-allergic action, antiviral effect, anticancer action and immunosuppressant action, etc., against multiple systemic and non-systemic diseases. ${ }^{5,6}$ In the past and present various animal models and experiments had proved the reduction in oxidative damage related disorders when there is dietary antioxidants/flavonoids supplementation. ${ }^{7}$

Flavonoids are responsible for anti-oxidant effect by various mechanisms. For example free radical scavenging, inhibiting the system enzymes that induces free radical generation, etc. ${ }^{8}$ Quercetin, a common naturally distributed flavonoid which has several pharmacological effects, including an established antiulcerogenic activity against various animal models and against different methods of ulcer induction, e.g., ethanol induced, acetic acid induced, stress induced and due to pyloric occlusion. ${ }^{9-12}$ Hence, with the use of flavonoids the relapse phenomenon of PUD which is the major drawback in anti-secretory agents utilization, could be turned over to permanent cure by these cytoprotective and antioxidant effects of quercetin against histamine induced gastric ulcers.

\section{METHODS}

This quercetin study was undertaken at the Central Animal House of Mahatma Gandhi Medical College and
Research Institute (MGMCRI), SBV Deemed to be University, Pillaiyarkuppam, Puducherry, India-607402. The study was undertaken in accordance with, "Guide for the Care and Use of Laboratory Animals" (NIH-1985). The Institutional Animal Ethics Committee (IAEC686/PO/Re/S/02/CPCSEA) approved this study in April 2016 [proposal number 03/IAEC/MG/01/April 2016].

\section{Chemicals and reagents}

- Quercetin powder (3, 5, 7, 3', 4'pentahydroxyflavone) was procured from Sigma Aldrich, Chennai.

- Promethazine hydrochloride and histamine acid phosphate injection from Sigma Aldrich, Chennai.

- Ranitidine tablets procured from the pharmacy of MGMCRI, Puducherry.

- Tissue MDA, SOD and CAT, and Plasma MDA, SOD and CAT kits were procured from MP Biomedicals, Maharashtra, Mumbai [Ransod and Ransel and Randox Laboratories $\mathrm{GmBH}$, from Netherland (Manufacturer)].

- Injection Ketamine from pharmacy, MGMCRI, Puducherry.

\section{Animals used}

24 male guinea pigs were used in this study. Animals weighing 300-400 $\mathrm{g}$ were included in this study. The animals were housed in the polypropylene cages with water and food (standard rat chow diet) ad libitum and acclimatized for one week. Male guinea pigs were purchased from TANUVAS, Chennai, Tamil Nadu.

The animals were maintained under standard laboratory conditions (12 hours light and dark cycle, temp 20-25 degree celsius, and humidity 50-55\%), divided into four groups of six in each group $(n=6)$ after one week of acclimatization.

\section{Study design}

24 male guinea pigs are divided into 4 groups $(n=6)$ as follows.

\section{Group I}

Normal control given $1 \mathrm{ml}$ of distilled water per orally 45 mins prior to $1 \mathrm{ml}$ distilled water intraperitoneal injection.

\section{Group II}

Disease control given $1 \mathrm{ml}$ of distilled water per orally 45 mins prior to $1 \mathrm{ml}$ histamine acid phosphate intraperitoneal injection. 


\section{Group III}

Quercetin $200 \mathrm{mg} / \mathrm{kg}$ in distilled water per orally $45 \mathrm{mins}$ prior to $1 \mathrm{ml}$ histamine acid phosphate intraperitoneal injection.

\section{Group IV}

Ranitidine $100 \mathrm{mg} / \mathrm{kg}$ in distilled water per orally 45 mins prior to $1 \mathrm{ml}$ histamine acid phosphate intraperitoneal injection

\section{Preparation of test solutions}

- Ranitidine tablets were dissolved in distilled water and prepared a solution containing ranitidine 25 $\mathrm{mg} / \mathrm{ml}$.

- Quercetin powder was dissolved in distilled water and prepared a solution containing quercetin 50 $\mathrm{mg} / \mathrm{ml}$.

\section{Induction of gastric ulcers}

24 male guinea pigs were fasted over 36 hours. Animals in Group II, III and IV are injected with $1 \mathrm{ml}$ of histamine acid phosphate intraperitoneal injection (50 $\mathrm{mg}$ base), to induce gastric ulcers. To prevent toxicity due to histamine injection, $5 \mathrm{mg}$ of promethazine hydrochloride is injected intraperitoneally $15 \mathrm{mins}$ prior and $15 \mathrm{mins}$ after histamine intraperitoneal injection. The test drugs quercetin $(200 \mathrm{mg} / \mathrm{kg})$ prepared in $50 \mathrm{mg} / \mathrm{ml}$ solution and ranitidine $(100 \mathrm{mg} / \mathrm{kg})$ prepared in $25 \mathrm{mg} / \mathrm{ml}$ solution were given via infant feeding tube/feeding needle per orally for Group III and Group IV male guinea pigs, respectively 45 mins prior to histamine acid phosphate injection.

Four hours after intraperitoneal injection of Histamine acid phosphate, all the 24 male guinea pigs were sacrificed by intramuscular ketamine injection and their stomach tissues were dissected out. ${ }^{13}$

\section{Sample collection and preparation}

Step1: The chest wall of the male guinea pigs followed by their abdominal cavity was cut open.

Step 2: Collection of intra cardiac blood sample which was incubated to clot and then the plasma extracted after incubation was utilized for anti-oxidants (MDA, SOD, CAT and GSH-Px) evaluation by storing the sample at-20 degree Celsius.

Step 3 : Lower esophageal and pyloric ends were ligated to finally dissect out the stomach tissue of the guinea pig and a part of it was utilized for tissue antioxidants (MDA, SOD, CAT, GSH-Px) level estimation..$^{14,15}$

\section{Measurement of MDA, SOD and GSH-PX in gastric tissue of guinea pigs}

Tissue MDA (Malondialdehyde) $(\mu \mathrm{mol} / \mathrm{L})$ was determined using the Double heating method of Draper and Hadley. ${ }^{16}$ Tissue SOD (U/mg) and GSH-Px (U/mg) levels were estimated using commercial kits from Ransod and Ransel and Randox Laboratories $\mathrm{GmbH}$, respectively with spectrophotometer (Shimadzu UV-1601) utilization. ${ }^{17,18}$

\section{Serum estimation of MDA, SOD, CAT levels}

The measurement of MDA is done indirectly to estimate the lipid peroxidation. ${ }^{19}$ The level of MDA in the plasma were calculated using the reaction of MDA with thiobarbituric acid. ${ }^{20}$ SOD estimation in plasma was carried out using Randox kits (Randox Laboratories). ${ }^{21}$ CAT reaction was estimated with the Method of Aebi. ${ }^{22}$

\section{Statistical analysis}

The values of biochemical analysis were expressed as mean \pm SD for six rats in a group $(n=6)$. Data analyzed by Duncan's multiple range test (DMRT) using SPSS software. The probability of $p<0.05$ will be taken as statistically significant.

\section{RESULTS}

\section{Effect of quercetin on stomach tissue antioxidant levels}

From Table 1, the estimated gastric tissue MDA levels increased from $75.98 \pm 0.35 \mu \mathrm{mol} / \mathrm{g}$ in Group I to $158.18 \pm 0.06 \mu \mathrm{mol} / \mathrm{g}$ in Group II $(\mathrm{p}<0.001)$. But on coadministration of quercetin $(200 \mathrm{mg} / \mathrm{kg}, \quad \mathrm{PO})$ and ranitidine $(100 \mathrm{mg} / \mathrm{kg}, \mathrm{PO})$ with histamine IP injection in Group III and Group IV, the MDA levels decreased to $76.98 \pm 0.71 \mu \mathrm{mol} / \mathrm{g}$ and $79.28 \pm 0.11 \mu \mathrm{mol} / \mathrm{g} \quad(\mathrm{p}<0.001)$ respectively.

From Table 1, the estimated Superoxide dismutase (SOD) levels decreased from $28.93 \pm 2.10 \mathrm{U} / \mathrm{mg}$ protein in Group I to $9.27 \pm 0.44 \mathrm{U} / \mathrm{mg}$ protein in Group II $(\mathrm{p}<0.001)$. When quercetin $(200 \mathrm{mg} / \mathrm{kg}, \mathrm{PO})$ and ranitidine $(100 \mathrm{mg} / \mathrm{kg}$, PO) were co-administered with histamine IP injection in Group III and Group IV the values of SOD increased to $29.35 \pm 0.89 \mathrm{U} / \mathrm{mg}$ protein and $27.83 \pm 0.22 \mathrm{U} / \mathrm{mg}$ protein $(\mathrm{p}<0.001)$ respectively.

From Table 1, the estimated glutathione peroxidase (GSH-Px) level was reduced to $0.013 \pm 0.57 \mathrm{U} / \mathrm{mg}$ protein in Group II from $0.692 \pm 0.10 \mathrm{U} / \mathrm{mg}$ protein $(\mathrm{p}<0.001)$ in Group I. When quercetin $(200 \mathrm{mg} / \mathrm{kg}, \mathrm{PO})$ and ranitidine $(100 \mathrm{mg} / \mathrm{kg}, \mathrm{PO})$ were co-administered with histamine IP injection in Group III and Group IV the values of GSHPx increased to $0.645 \pm 0.72 \mathrm{U} / \mathrm{mg}$ protein and $0.501 \pm 0.19$ $\mathrm{U} / \mathrm{mg}$ protein $(\mathrm{p}<0.001)$ respectively. 
From Table 2, it is noticed that similar to the gastric tissue antioxidant levels the SOD and CAT levels in Group II was the least compared to the Group I which was the normal control, Group III and Group IV treated with quercetin $(200 \mathrm{mg} / \mathrm{kg}, \mathrm{PO})$ and ranitidine (100 $\mathrm{mg} / \mathrm{kg}, \mathrm{PO})(\mathrm{p}<0.001)$. The plasma MDA level was the highest in Group II (PUD control) which depicts the extreme level of lipid peroxidation. Compared to Group II, Group III and Group IV, treated with quercetin (200 $\mathrm{mg} / \mathrm{kg}, \mathrm{PO})$ and ranitidine $(100 \mathrm{mg} / \mathrm{kg}, \mathrm{PO})$ respectively showed an increase in the level of MDA near to the level of Group I animals (normal control) $(\mathrm{p}<0.001)$.

Table 1: Effect of quercetin on stomach tissue antioxidants.

\begin{tabular}{|llll|}
\hline Groups & $\begin{array}{l}\text { SOD } \\
(\text { U/mg protein) }\end{array}$ & $\begin{array}{l}\text { GSH Px } \\
(\text { U/mg protein) }\end{array}$ & $\begin{array}{l}\text { MDA } \\
(\mu \mathrm{mol} / \mathrm{g})\end{array}$ \\
\hline Normal control & $28.93 \pm 2.10^{\mathrm{b}}$ & $0.692 \pm 0.10^{\mathrm{a}}$ & $75.98 \pm 0.35^{\mathrm{d}}$ \\
\hline PUD control & $9.27 \pm 0.44^{\mathrm{d}}$ & $0.013 \pm 0.57^{\mathrm{d}}$ & $158.18 \pm 0.06^{\mathrm{a}}$ \\
\hline PUD+quercetin $(\mathbf{2 0 0 m g} / \mathbf{k g})$ & $29.35 \pm 0.89^{\mathrm{a}}$ & $0.645 \pm 0.72^{\mathrm{b}}$ & $76.98 \pm 0.71^{\mathrm{c}}$ \\
\hline PUD+ ranitidine $(\mathbf{1 0 0} \mathbf{m g} / \mathbf{k g})$ & $27.83 \pm 0.22^{\mathrm{c}}$ & $0.501 \pm 0.19^{\mathrm{c}}$ & $79.28 \pm 0.11^{\mathrm{b}}$ \\
\hline
\end{tabular}

Values are expressed as means \pm SD for six rats in each group. Values not sharing a common superscript differ significantly at $\mathrm{p}<0.05$ (Duncan's test). For SOD and GSH PX: Level of significance as $(d<c<b<a)$; for MDA: Level of significance as $(a<b<c<d)$.

Table 2: Effect of quercetin on plasma antioxidants.

\begin{tabular}{|llll|}
\hline Groups & $\begin{array}{l}\text { SOD } \\
(\mathbf{U} / \mathbf{m g} \mathrm{Hb})\end{array}$ & $\begin{array}{l}\text { CAT } \\
(\mathrm{U} / \mathrm{g} \mathrm{Hb})\end{array}$ & $\begin{array}{l}\text { MDA } \\
(\mathbf{n m o l} / \mathbf{m l})\end{array}$ \\
\hline Normal control & $1737.8 \pm 1.13^{\mathrm{b}}$ & $298.6 \pm 0.30^{\mathrm{a}}$ & $1.90 \pm 0.33^{\mathrm{d}}$ \\
\hline PUD control & $1489.8 \pm 0.23^{\mathrm{d}}$ & $217.5 \pm 0.76^{\mathrm{d}}$ & $2.98 \pm 0.16^{\mathrm{a}}$ \\
\hline PUD+quercetin $(\mathbf{2 0 0 m g} / \mathbf{k g})$ & $1787.3 \pm 0.45^{\mathrm{a}}$ & $286.9 \pm 0.32^{\mathrm{b}}$ & $2.04 \pm 0.31^{\mathrm{c}}$ \\
\hline PUD+ ranitidine $(\mathbf{1 0 0 m g} / \mathbf{k g})$ & $1709.8 \pm 0.23^{\mathrm{c}}$ & $275.5 \pm 0.24^{\mathrm{c}}$ & $2.23 \pm 0.13^{\mathrm{b}}$ \\
\hline
\end{tabular}

Values are expressed as means \pm SD for six rats in each group. Values not sharing a common superscript differ significantly at $p<0.05$ (Duncan's test). For SOD and GSH PX: Level of significance as $(\mathrm{d}<\mathrm{c}<\mathrm{b}<\mathrm{a})$; for MDA: Level of significance as $(\mathrm{a}<\mathrm{b}<\mathrm{c}<\mathrm{d})$.

\section{DISCUSSION}

The free radicals derived from oxygen have high implication in the pathogenesis of multiple clinical disorders and gastric ulceration in both human and experimental animals. ${ }^{23}$ The available drugs for PUD at present focuses only on neutralization of acid (with $\mathrm{H} 2$ blockers) and interfering with secretion of acid (PPIs). ${ }^{24}$ Quercetin, a flavonoid identified from many frequently consumed food products (berries, apples, tea, onion and green vegetables) have been reported with multiple beneficial effects (anticancer, antiulcer, anti-allergic, antiviral, anti-inflammatory, cataract prevention, cardiovascular protection, etc.,) on human population. ${ }^{25}$

Though anti-ulcerogenic effect of quercetin is proved in various PUD models, studies on the effect of quercetin on histamine induced gastric ulcer models are very meagre. The aim of the present study was to provide supportive evidence to prove that quercetin is also effective against the oxidative stress induced gastric damage caused by histamine intraperitoneal injection, and prove the antioxidant effect against this model of PUD induction. The level of lipid peroxidation determines the level of oxidative stress induced gastric tissue damage. MDA levels are considered as the best indicators of lipid peroxidation. The antioxidant enzymes SOD, GSH-Px and CAT indicates the protective enzymatic activity against tissue damage. This biochemical markers of tissue destruction are estimated in the gastric tissue and in the serum samples collected from the guinea pigs.

This study showed a significant $(\mathrm{p}<0.001)$ increase in tissue and serum MDA levels in the PUD induced group and the levels were near normal or significantly less $(\mathrm{p}<0.001)$ in treated groups. The antioxidant enzymes SOD and GSH-Px levels in the tissues significantly $(\mathrm{p}<0.001)$ high in the quercetin $(200 \mathrm{mg} / \mathrm{kg}, \mathrm{PO})$ and ranitidine $(100 \mathrm{mg} / \mathrm{kg}, \mathrm{PO})$ treated groups when compared to the PUD induced group. The antioxidant enzymes SOD and CAT levels in the serum also showed a significant hike $(\mathrm{p}<0.001)$ in the quercetin $(200 \mathrm{mg} / \mathrm{kg}$, $\mathrm{PO})$ and ranitidine $(100 \mathrm{mg} / \mathrm{kg}, \mathrm{PO})$ treated groups when compared to the PUD induced group.

With this the anti-ulcerogenic property of quercetin due to its anti-oxidant effect is evident and can be termed as universal anti-ulcerogenic agent which even prevents frequent relapses. So the primary objective of the present study was to evaluate the anti-oxidant effect of quercetin in histamine induced gastric ulcers, which was successfully estimated and evidenced with the level of various antioxidants in gastric tissue samples and serum samples. 


\section{CONCLUSION}

In summary quercetin, a natural phenolic compound available in the plant kingdom, has proved its antioxidant property by the reduction in the induction of lipid peroxidation with MDA levels as their indicator and increase in the antioxidant enzymatic activity with increased levels of SOD, CAT and GSH-Px levels as their indicator in the quercetin treated group which were in par with the available anti-secretory agent, ranitidine. And now with this available results the thirst towards more permanent cure for PUD would be satisfied, and when further studies proves the gastro-protective effect and induction of regeneration of gastric tissue, the above evidence would be more substantiating towards the antioxidant tissue protection effect of quercetin in experimental animal models.

\section{ACKNOWLEDGEMENTS}

I would like to thank the Biochemistry Department, (MGMCRI, Puducherry) and the Pathology Department (CMC, Vellore) for providing laboratory assistance in analyzing the samples used in this study.

\section{Funding: No funding sources}

Conflict of interest: None declared

Ethical approval: The study was approved by the Institutional Animal Ethics Committee

\section{REFERENCES}

1. Sabiston's Textbook of General Surgery- a biological basis of modern surgical practice- stomachepidemiology of peptic ulcer disease. In: Courtney TM, Daniel BR, Mark EB, Kenneth ML, eds. 19th ed. Elsevier; 2011: 1191-1192.

2. Brunicardi C, Anderson DK, Billiar TR, Dum DL, Hunter JH, Mathews JB. Schwartz's Principles of Surgery. 9th ed. Mc Hills Publishers; 26(1): 425454.

3. Bhat SM, Rao P. SRB's manual of surgery- stomach. 4rd ed. New Delhi, India: Jaypee Brothers Medical Publishers; 2003: 745-796.

4. Bailey and Love's Short practice of surgery-stomach and duodenum. In: Williams $\mathrm{N}$, O'Connell PR, McCaskie A. 27th ed. CRC Press; 2004: 1045-1065.

5. Martin MJ, Casa CL, Lastra CA, Cabeza J, Villegas I, Motilva V. antioxidant mechanisms involved in gastroprotective effects of quercetin. Zeitschrift fur Naturforschung; 1998;53:82-8.

6. Havsteen B. Flavonoids a class of natural products of high pharmacological potency. Biochem Pharmacol. 1993;32:1141-5.

7. Narayanamurthy U, Santhakumari S, Nirmala P. Nephroprotective effect of Silymarin in hyperglycemia induced oxidative stress in rats. Int $\mathbf{J}$ Basic Clin Pharmacol. 2014; 6(7):34-42.
8. Ross JA, Kasum CM. Dietary flavonoids: bioavailability, metabolic effects and safety. Annu Rev Nutr. 2002;22:19-34.

9. Kelly GS. Quercetin-monograph. Official J Am Coll Adv Med. 2011;16(2):171-94.

10. Lastra AC, Martin MJ, Motilva V. Antiulcer and gastroprotective effects of quercetin, a gross and histologic study. Pharmacol. 1994;48:56-63.

11. Motilva V, Martin MJ, Luque MI, Lastra AC. Role of polymorphonuclear leucocytes and oxygen derived free radicals in chronic gastric lesion induced by acetic acid in rats. Gen Pharmacol. 1996;27:545-50.

12. Martin MJ, Motilva V, Lastra AC. Quercetin and naringenin, effects on ulcer formation and gastric secretion in rats. Phytother Res. 1993;7:147-50.

13. Vogel GH. Drug discovery and evaluation: pharmacological assays. 2nd ed. Springer; 2002: 867872 .

14. Jainu M, Devi CS. Gastroprotective action of Cissus quadrangularis extract against NSAID induced gastric ulcer: role of pro-inflammatory cytokines and oxidative damage. Chem Biol Interact. 2006;161:262-70.

15. Khustar M, Kumar V, Javek K, Bhandari U. Protective effect of ginger oil on aspirin and pylorus ligation induced gastric ulcer model in rats. Ind $\mathbf{J}$ Pharm Sci. 2009;71:554-8.

16. Draper HH, Hadley M. Malondialdehyde determination as index of lipid peroxidation. Methods Enzymol. 1990;186:421-31.

17. Lowry $\mathrm{OH}$, Rosebrough NJ, Randall RJ. Protein measurement with the Folin phenol reagent. J Biol Chem. 1954;193:265-72.

18. Yoshikawa T, Y Naito, A Kishi, T Tomii, T Kaneko, $\mathrm{S}$ Iinuma, et al. Role of active oxygen, lipid peroxidation and antioxidants in the pathogenesis of gastric mucosal injury induced by indomethacin in rats. Gut. 1993;34:732-7.

19. Said MA, Nafeh NY. Protective effect of quercetin against indomethacin induced gastric ulcer in rat. Benha Faculty J. 2008;5:17-23.

20. Kahraman A, Erkasap N, Koken T, Serteser M, Aktepe F, Erkasap S. The antioxidative and antihistaminic properties of Quercetin in ethanol induced gastric lesions. Toxicol. 2003;183:133-42.

21. McCord JM, Fridovich I. Superoxide dismutase an enzymatic function for erythrocuprein (hemocuprein). J Biol Chem. 1969;244:6049-55.

22. Aebi H. Catalase. In: Bergmeyer HU. Textbook: Methods of enzymatic analysis. New York: Academic Press; 1974: 673-677.

23. Rao CV, Maiti RN, Goel RK. Effect of mild irritant on gastric mucosal offensive and defensive factors. Indian J Physiol Pharmacol. 1999;44:185-91.

24. Sairam K, Rao CV, Babu DM, Goel RK. Prophylactic and curative effects of Bacopa monnierain gastric ulcer models. Phytomed. 2001;8:423-30. 
25. De-Whalley C, Rankin SM, Houct S, Jessup W, Leake DS. Flavonoids inhibit the oxidative modification of low density lipoproteins by macrophages. Biochem Pharmacol. 1990;39:1743-50.
Cite this article as: Narayanamurthy U, Jayachandran R, Ramarajan SC, Kumarappan M, Kanan R,

Barathane D. Effect of quercetin on histamine induced gastric ulcers in male guinea pigs. Int $\mathrm{J}$ Basic Clin Pharmacol 2019;8:2018-23. 